\title{
Lessons from Research on Peace Education in Israel/Palestine
}

\author{
Gavriel Salomon
}

\begin{abstract}
Despite the relative uniqueness of peace education in contexts of intractable conflict, research on peace education carried out in the context of the Israeli-Palestinian conflict can be instructive, to a greater or lesser extent, in other contexts. Six researchbased lessons are presented: (1) The short life of peace education's positive effects and so the need for continuous reinforcement; (2) ways of restoring the eroded effects; (3) the benefits of learning about another conflict; (4) the differential effects of peace education on different groups of participants; (5) the limitations of peace education; and (6) joint projects with common important goals as an alternative approach to peace education. In addition, two common challenges facing peace education and other kinds of programs are presented: the challenge of maintaining the attained positive effects, and the challenge of spreading the effects to wider realms of society.
\end{abstract}

Keywords peace education, durability, social spread, psychological changes, collective narrative, adversary, induced compliance

Peace education has many meanings and a variety of practices depending on the socio-political context in which it takes place. For example, in Japan it means mainly anti-nuclear education, while in Northern Ireland it means education for mutual understanding between Protestants and Catholics. There are significant differences between peace education (1) in the context of ethnic tension with its focus on anti-racism (for the UK case, see Lentin 2004), (2) in the context of social tranquility but with a focus on classroom violence (Hakvoort 2010), and (3) in the context of actual political, often intractable, conflict between actual national or ethnic adversaries (for the Korea, Sudan, and Israel/Palestine cases, see Coleman 2003).

However, despite the differences between various political contexts, there are important commonalities among peace education programs. To illustrate, peace education aiming at resolving interpersonal misunderstanding (Morris and Harris 2003) is clearly different in many ways from peace education in the context of the conflict between Muslims and Hindus in India (Varshney 2002). Yet, when

(C) 2013 The Institute for Peace and Unification Studies, Seoul National University

E-ISSN 2288-2707 Print ISSN 2288-2693 
it comes to peace education, with its psycho-educational rather than political focus, the required conditions, for example, in the frame of the contact theory (Pettigrew and Tropp 2008), are relevant in both cases. More generally, lessons from peace education research, whether in the context of intractable conflict or in a more tranquil setting, aim to change minds and hearts in the direction of non-violence, tolerance, mutual understanding, empathy, and acceptance. To the extent that any lesson addresses these general goals, it may be widely applicable.

In this paper I present lessons that can be learned from research on peace education in Israel/Palestine. The conflict is intractable and it has lingered on for more than 100 years (Schulze 2008). Also, it has entailed outbursts of violence. Since the adversaries perceive it as a zero sum game, it occupies a central place in the people's minds and affects most aspects of daily life (Rouhanna and BarTal 1998). This conflict is based on mutually exclusive collective narratives and contrasting (yet symmetrical) beliefs such as "We are right and they are wrong," or "We are the victims while they are the perpetrators" (Salomon 2004; Bar-Tal and Salomon 2006).

The lessons are from a series of studies on the effects of in- and out-ofschool peace education programs. These programs focus on the psycho-social rather than on the political aspects of the conflict. They are educational rather than political in the sense that they attempt to change minds and hearts through learning to view the other side of the conflict as sharing a common humanity, and possessing a legitimate collective narrative. These desired changes pertain to the way in which the other side is perceived and related with, and these changes include changed attitudes, a greater willingness for contact, less extreme stereotypes, more positive feelings, and greater legitimization of the other side's collective narrative.

The peace education programs in this study are often characterized by dialogue encounters or by more interpersonal contacts between groups of young Jewish-Israelis and either Israeli-Palestinians or Palestinians from the occupied territories (Maoz 2010). Such encounters often last for two or three days in some relatively isolated place, or take place weekly for a whole school year. Many of these encounters are organized by non-governmental organizations (NGOs) as out-of-school activities. During dialogue encounters, whether confrontationoriented (Halabi and Sonnenshein 2004) or more interpersonally focused (Maoz 2004), the differences between the collective narratives come to the surface, painful mutual blaming takes place, and only very gradually do "dialogic moments" of mutual understanding emerge. These moments include some elements of mutual recognition, legitimization and acknowledgement of the contribution of one's own side to the conflict.

Joint projects represent another kind of encounter between Jews and Palestinians-for example, encounters involving pairs of schools, pairs of townships, or joint committee work. In these cases, the project or task to be 
carried out is the focus, while the conflict serves only as the background context rather than an issue to be directly confronted.

Despite its relatively unique nature, research on peace education in the Israeli/Palestinian context provides lessons that appear to be applicable across the board; they transcend the differences between socio-political contexts. Some of these lessons reaffirm what we always knew, but because of our enthusiasm and optimism about the value of peace education, we tended to ignore. Such is the case, for example, with the lessons that suggest that short-term educational interventions cannot have long-lasting effects, or that the same approach cannot serve everybody equally well. Other lessons are somewhat more surprising; for example, that learning about the conflict of another country may open one's eyes to see the conflict at home differently. However, other lessons are about the limits of peace education and what it cannot achieve; for example, that it can have impact on simple attitudes but not on strongly held convictions (Abelson 1988).

With this information as background, I turn to brief descriptions of some lessons that can possibly be applied regardless of particular contexts.

\section{Lesson 1: Socio-political Forces Can Override the Positive Impact of a Short Educational Intervention}

Peace education is often an attempt to go against the general current. Perhaps many in a society may be in favor of peace with the other side (country, tribe, ethnic group, or a minority), but when these views are confronted with political realities, they fall in line with the prevailing, less peace-oriented, and collective narrative. Indeed, the consensual collective narrative, with its shared sad historical memories (Roe and Cairns 2003), shared sense of identity (Gartzke 2006), and shared beliefs (Bar-Tal 2000), counters popular but simple views of making peace. In particular, the narrative conflicts with the goals of peace education, which are mutual understanding, legitimization of the other side's collective narrative, and cross-divide contact (Salomon 2004). For example, according to recent surveys (Smooha 2010), while a large majority of Israeli Jews (79\%) believes that the Israeli-Palestinians should have full and equal civil rights, $77 \%$ of them think that major decisions about peace terms and borders between Israel and Palestine should be decided by the Jewish majority alone; and while $81 \%$ of the IsraeliPalestinians accept being citizens of the State of Israel, only $20 \%$ of them identify themselves as such. The forces of the belligerent collective narratives are clearly evident in these inconsistent responses.

It also becomes more evident that in light of the dominance of each side's consensual collective narrative, peace education becomes a somewhat subversive activity with some explicit, but mainly implicit, messages that are not easily shared by the socio-political forces in the wider society. 
Figure 1. Generalized Graph of Pre- to Delayed Post-test Changes of Different Variable

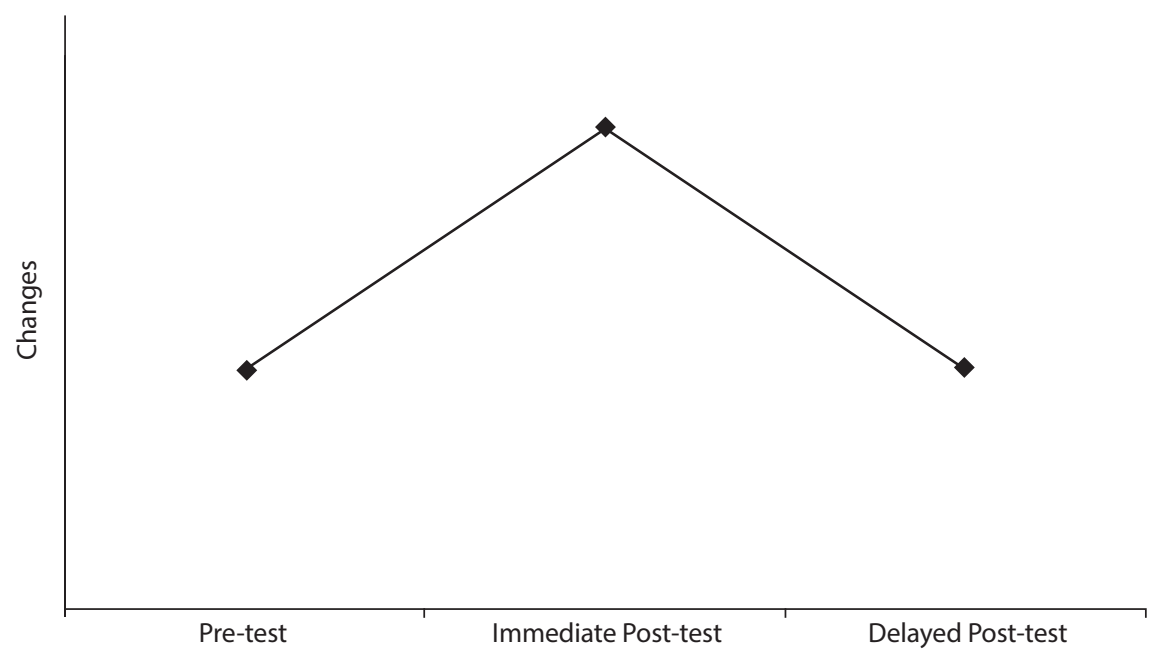

This phenomenon is reflected in the fleeting effects of peace education. Research consistently shows that relatively short peace education interventions have positive effects on attitudes, feelings, stereotypes, and willingness for contact. Also, these positive effects become eroded after a short while (Salomon 2006). The measured positive impact shows a return to baseline values, as if the individuals measured never participated in a peace education program (see Figure 1).

It is evident that the more conciliatory narrative developed through peace education is too unstable when it faces the prevailing collective narrative. One's social surroundings, significant others, the media, peers-and above all, the overriding political atmosphere-can easily erode the changes attained through peace education. This kind of erosion pertains to changed attitudes, changed stereotypes, changed feelings, and willingness for contact, and it is true for both sides of a conflict.

The first lesson is that short-term interventions usually yield only shortterm effects; desired changes of hearts and minds need continuous reinforcement and scaffolding. A second lesson is methodological: A researcher should never be satisfied with measured changes taken only "the morning after." Measurement needs to be taken a while after the completion of a peace education program in order to evaluate the extent to which lasting changes have taken place.

\section{Lesson 2: Eroded Effects Can Be Restored}

If Lesson 1 could easily discourage peace educators, there is still room for hope. 
Figure 2. Restoring Changes by Induced Compliance



Source: Rosen and Salomon 2011.

The effects that seem to have disappeared are not really lost; they are eroded but can be restored by particularly focused post-program interventions. Three such interventions have been empirically studied with encouraging results. One such intervention is based on the induced compliance paradigm (Leippe and Eisenstadt 1994), known to educators as role-playing. Individuals who have participated in a peace education program are asked to share with others the views of the other side-views they oppose but to which they have been exposed. Imagine Israeli-Jewish peace education participants standing in front of their peers and presenting the essence of the Palestinian narrative. The peers are instructed to challenge the actors who are expected to defend their adversary's views (Rosen and Salomon 2011). Interesting things happen. The actors hear themselves defending the views of their adversary which causes cognitive dissonance that has to be reduced: There is a perceived discrepancy between the actors' beliefs and the position they are now vocally defending. The actors cannot resolve this state of cognitive dissonance by denouncing their own action of defending the other side's position, but they can change their attitudes by agreeing to some extent with the other side. In so doing the actors "discover" certain arguments they have chosen to ignore thus far and the merits of the other side's views, thereby moving their views closer to those of their adversary. Compared with a control group that did not undergo induced compliance, the eroded effects are restored and sustained (see Figure 2).

In a second study (Jayusi 2009), peace education participants were asked to share with younger peers what they have experienced during a peace education program. This method of peer instruction (Damon and Phelps 1989) has a similar restorative impact on the eroded effects: Participants are able to mindfully examine the events experienced in the peace education program 
and such reflection allows the revival of the eroded effects. Similar results have been obtained by having peace education participants reflect back on the peace education program in which they have participated (Arnon 2010). They were asked to write down what they liked, disliked, and what changes they wanted to see in the program.

The common core of the effect-restoring interventions is their reflective nature. Reflection allows for more metacognitive self-regulation and monitoring. Thus, one comes to sidestep the resistance and reflexive hostility that are automatically aroused by listening to the other side's provocative arguments (Siegel 2007). One may not like the adversary's arguments, but reflection makes one aware that totally ignoring, evading or resisting them conflicts with one's self image as an intelligent and open-minded individual (Rodgers 2002).

Lesson 2 is that positive changes brought about by a peace education approach, whereby the perspectives of the other side are heard and one's own views are expressed and challenged, where one comes to know the "others" and empathizes with them, cannot be totally erased. They may be suppressed by the prevailing collective narrative, but they can still be restored and revived.

\section{Lesson 3: Facilitate Study of Other Conflicts}

People need to learn about the conflicts in which their own societies are involved, including the adversary's collective narrative. Ignorance feeds prejudice (Bowen 2001), entrenchment, and mindless acceptance of the prevailing collective narrative (Langer 1997). This much is obvious. What is less obvious is that learning about somebody else's conflict can circumvent the quite automatically aroused rejection of the collective narrative of the adversary in the conflict facing one's own society. For if you attempt to educate individuals about their adversary's perspective in their own conflict, you are very likely to face objections and rejection since you threaten their firmly held belief in the righteousness of their collective narrative. Not so when you allow them to discover the complexity and many-sidedness of somebody else's conflict.

In one study, Jewish high school students familiar with the Israeli/Palestinian conflict studied in small teams the Northern Ireland conflict, analyzing the arguments of both sides and the way the conflict escalated. When the students were subsequently asked to write about the Israeli/Palestinian conflict as seen through Jewish eyes, no differences were found between these students and a control group who did not study the Irish conflict. Students in both groups echoed what they had learned in school: the Jewish collective narrative. However, when the two groups were asked to write about the conflict from the Palestinian perspective, huge differences emerged. Most students in the control group resisted taking the Palestinian point of view, and the few who did so painted a 
rather hateful picture of the Palestinians. The students who studied the Northern Ireland conflict showed very different results. Their descriptions were balanced, fair, and far more objective. It appeared that they had learned to see the twosidedness of the conflict and its complexity. They could even reveal a modicum of empathy with the Palestinians that the students in the control group could not and would not exhibit.

Coming to see the other side's perspective may not lead one to agree with that perspective, but it can lead to the legitimization of that point of view. One comes to see that the other side has its own legitimate goals and its own history; one can come to see the other side's humanity (Wu and Kaisar 2007). This is very much what peace education desires: To change the one-sided, monolithic point of view ("We have God on our side; they don't.") into a more multi-sided one that, in part at least, acknowledges the contribution of one's own side to the conflict (BarOn 2000). This entails some changes in one's self-image ("We are right, but only part of the time.") as well as reduced certitude in one's adherence to the received collective narrative.

\section{Lesson 4: One Size Does Not Fit All}

More often than not, peace education programs-for children, adolescents, or adults-are uniform, based on the same principles yet addressing members of adversarial groups. However, as we now know, adversarial groups come with quite different views of the conflict, have different expectations, process the events differently, and emerge with different kinds of effects. In one study (Biton and Salomon 2006), Jewish-Israelis and Palestinians were asked to present their visions of peace. While most of the Israeli participants saw peace as a reduction of violence (according to Galtung [1996], this is negative peace), the Palestinians saw peace as entailing independence and equality (structural peace). It became evident that both groups approached peace education with entirely different conceptions of peace and thus ended up with different effects.

This was clearly shown in a study (Husisi 2007) that was based on a year-long school-based peace education program that addressed three spheres concerning the "other": "The other inside me" - to arouse self-awareness; "the other near me" - to help understand and tolerate others in one's immediate surroundings; and "the distant other" - to cultivate tolerance for Palestinians or Jews. For each sphere the program focused on the values one chooses to live by, knowledge of the conflict and the "other," and skills for reconciliatory behavior. Unlike other programs, this one did not include face-to-face meetings between Israelis and Palestinians, but was carried out separately but simultaneously in Jewish and Palestinian schools. The program was embedded in regular school curricula such as literature, historys, and sociology for two hours a week, and lasted for six to 
Figure 3. Legitimizing One's Own or the Other's Collective Narrative

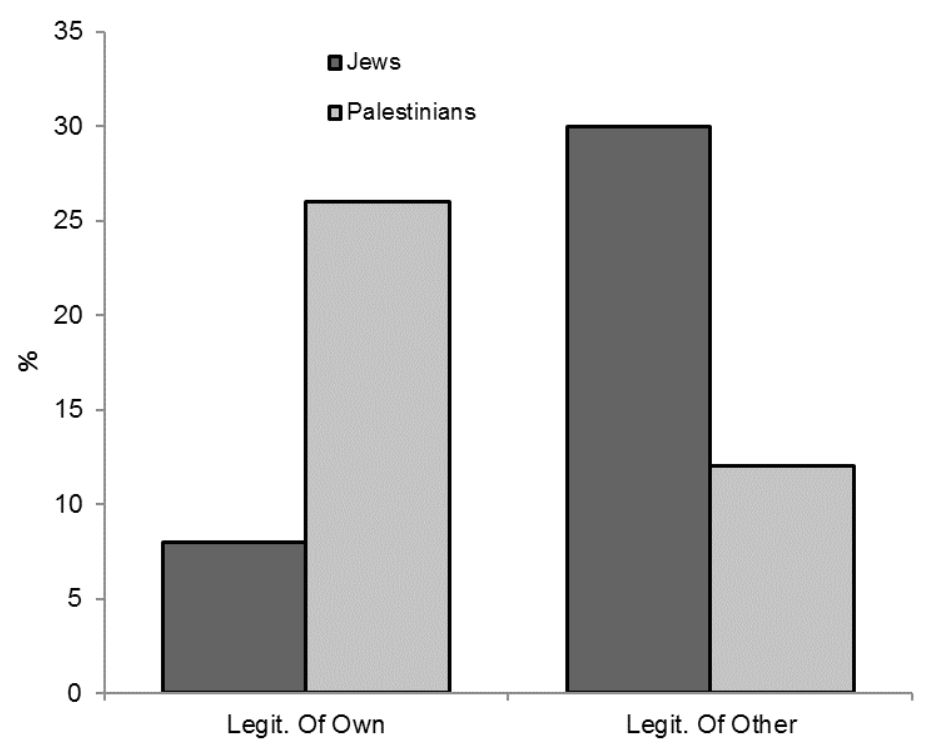

Source: Husisy 2007.

eight months of the school year.

Israeli Jews participating in the program manifested greater acceptance of the legitimacy of the Palestinian collective narrative. The Palestinians, on the other hand, manifested stronger adherence to their own collective narrative. They viewed participation in the peace education program as serving their own goals as a minority (see Figure 3 ).

Shnabel and Nadler (2009) developed a model of needs-based inter-group reconciliation and showed that while a victimized minority (e.g., Palestinians) aims to regain its power by "having a voice," the majority (e.g., Israeli Jews) desires to regain its social and moral acceptance. Satisfying the needs of both sides can lead to effective reconciliation. In other words, a uniform program that addresses only one side's needs, or neither type of need, disregards the deepseated differences between the two groups. Thus, applying a uniform approach is not likely to be very effective. Effective peace education requires addressing the different needs, aspirations, and motivations of all involved.

\section{Lesson 5: Peace Education Has Its Limitations}

It is claimed that the overall goal of peace education is the legitimization of the other's collective narrative. This involves acknowledgment of what one's own side has done to the other. It also entails increased empathy and changed mindsets- 
for example, reduced stereotypes and prejudices, more positive attitudes, and the like (Salomon 2002). However, not all attitudes are born alike; some may be more amenable to educational intervention than others. Indeed, Abelson (1988) distinguished between attitudes and convictions. The former comprises common viewpoints in which no strong feelings are involved. The latter, on the other hand, are attitudes or beliefs that are particularly strongly held; they are central to one's system of attitudes and beliefs; one's ego is involved and so they are accompanied by strong feelings. For example, think about how strongly the beliefs about vegetarianism are held by truly believing, practicing vegetarians; and how deeply the beliefs about women's rights are felt among adherents to feminism. Most importantly, convictions are resistant to change (Krosnick and Petty 1995).

Rosen and Salomon (2011) carried out a study in which university students were asked to rate certain narrative-based statements for their importance and centrality. For each side of the local conflict some statements provided to the students were assumed to be central and hence held with greater force, while other statements were assumed to be more marginal. Rosen found, as expected, that attitudes ("I can trust the Palestinians.") were affected by a peace education program, but convictions ("We have the historical right to this land.") were not. The latter serves as the backbone of a collective narrative, and changing them would shake one's whole belief structure. However, as already pointed out in Lesson 1 , simple attitudes that can be changed by educational interventions can just as easily be reversed by stronger socio-political forces.

The idea then is to strengthen, scaffold, and reinforce the attained attitudinal changes. Convictions - those strongly and centrally held attitudes that serve as the backbone of one's belief system-can be changed, if at all, only by dramatic events, strong, even traumatic, personal experiences, or slow societal normative changes (Peterson and Hagan 1984). However, these are not within the reach of usual peace education programs. In all, peace education can be effective under certain conditions, but it has its limits (Ross 2000): Attitudes have a fair chance of being affected by peace education, but not so convictions.

\section{Lesson 6: Dialogue Is Not the Only Method of Peace Education}

One can hardly think of peace education without actual face-to-face (or more rarely, virtual) contact. More often than not such contact involves some kind of dialogue. The dialogue can range from confrontational (Halabi and Sonnenshein 2004) to an approach that is more interpersonally oriented (Maoz 2010). However, contact involving dialogue need not be the only way to conduct peace education and it is also possibly not the most effective way. An alternative approach is to carry out joint projects that have common goals to be jointly attained. The projects need not be related to peace education nor educationally 
designed. In fact, most joint, bi-national or bi-ethnic projects are designed-if designed at all-to attain a particular academic, athletic or business goal with no overt educational intention.

Often peace education takes place unintentionally or incidentally during joint activities designed to accomplish particular tasks and attain particular goals that have little to do with the traditional goals of formal peace education. Examples of such activities are inter-racial soccer clubs where blacks and whites train and play together (Brown et al. 2003), multi-ethnic businesses where Muslims and Hindus work together (Varshney 2002), and joint medical teams of Jews and Palestinians in hospital wards (Desivilya 1998).

Working, training, playing, and preparing a project together appear to meet all the conditions of the contact theory (Pettigrew and Tropp 2008), thereby increasing the chances of attaining the goals of peace education even without this being the motivation behind the activity. There is usually a common goal and all cooperate in pursuing it; there is a necessary interdependence between the participants; there is institutional support for cooperation; and there is potential for friendship.

In one study, the effects of yearlong participation in three bi-national (Jewish/ Palestinian) football clubs were compared with the experience of uni-national clubs in terms of changed prejudices, attitudes, and feelings toward the other side (Zuobi 2007). This much is clear: Training together twice a week, playing a match twice a month, and having the parents of both sides join forces to support "their" teams meet all the contact theory conditions and should have positive effects. Indeed, these were the encouraging findings by Zuobi. However, Desivilya's findings in relation to joint medical teams in a northern Israeli hospital were somewhat less encouraging. She asked whether the joint work of the JewishPalestinian teams could overcome national animosities, stereotypes, and prejudices, and thereby generalize beyond the parameters of the joint work place. She did not find such positive transferable effects.

The study by Zuobi (2007) highlighted two additional conditions that facilitate the attainment of changed hearts and minds. One such condition is continuity. During the year of joint activity, friendships can emerge, better understanding and appreciation of the other team members can deepen, and as one would hope, generalization from the individual team members to their respective national groups can be attained. As we have seen in Lesson 1, shortterm interventions have only short-term effects. Continuity, in this regard, is essential. The second additional lesson or condition that bi-national goal-oriented activities appear to meet is the importance of the common goal in the eyes of the participants. It is essential for the participants to win football matches, to stage a successful joint musical performance, to reach business goals, or to jointly win a case in court. It is the importance of the goal that paves the way to transcending ethnic or national differences. 
Planned peace education is not involved in these circumstances. The effects of this kind of peace education are no more than side effects, rarely intended and rarely designed for. As such, acting jointly to attain a common goal of importance overshadows national or ethnic tensions while dialogue encounters do not always accomplish this outcome. This then appears as yet another mode of peace education.

\section{Reflection}

I started this paper by pointing out how peace education can be approached in different socio-political contexts. Nevertheless, I also claimed that the lessons learned from research on peace education in the context of an intractable conflict may be applicable in other contexts as well. Looking back on the lessons described here, are they indeed so widely applicable? After all, peace education that is based on contact between adversaries may not be relevant to situations where it is based on interpersonal conflict resolution through mediation, or to peace education focusing on disarmament.

One needs to be more specific. While some lessons may be applicable across the board, other lessons may be more limited in application. Consider, for example, empirical lessons demonstrating that peace education needs to be a continuous activity lest its effects become eroded. This is not a context-specific lesson; it can apply to all peace education programs regardless of context or particular goals. The same is true for the lesson that joint goal-oriented activities may yield peace education-related effects; this lesson need not be limited to situations where activities are carried out jointly by adversaries. Indeed, even in the absence of an adversary, there can be deep-seated differences between groups based on sex, age, social role, or status. Joint activities can help bridge such differences. On the other hand, the lesson that studying another conflict can be an eye-opener may apply to more limited contexts where a conflict between adversaries is actually experienced, but not in other cases.

Beyond the question of the relevance of the lessons in various contexts, there are still two important commonalities to be considered. These two points are not lessons learned from empirical research, but challenges emanating from the general limitations of any socially oriented educational intervention, and pertaining particularly to peace education interventions. One challenge concerns the durability or sustainability of the attained effects, and the other to widening the social circle of those affected.

Durability: Regarding the frequent erosion of peace education's effects, this lesson applies to most other interventions that are designed to change socially oriented minds and hearts. Protecting the environment, saving electricity, and loving one's neighbor can be examples. Here is the challenge: It is crucial to 
provide continuous scaffolding and reinforcement to maintain the attained changes lest they return to their initial states. There are no quick and easy peace education interventions with lasting effects.

Spreading the gospel: It is important to have positive impact on the minds and hearts of participants in peace education programs (or for that matter, any other educational program), but this is not sufficient. To a large extent, hard feelings, animosity, fear, hatred, distrust, and anger emanate from a society's shared collective narrative (Polkinghorne 1988). Therefore, peace education programs need to affect not only those who actually participate in the programs, but the effects need to spread to other realms of society. This kind of ripple effect cannot be achieved only by having school-based programs, weekend dialogue encounters, and bi-ethnic or bi-national football clubs in which only a handful of individuals can participate. The challenge, then, is to involve others-parents, neighbors, friends, colleagues and such-through a process that may require society-wide motivation (Salomon 2011).

Indeed, where peace education attempts to counter prevailing norms and instill others (e.g., human rights, social justice, ethnic tolerance), the question of the political climate and social motivation becomes crucial. It is extremely difficult to convince participants in peace education programs to empathize with "the other" or to step into "the other's shoes" where an opposing collective narrative prevails and dominates. It might well be the case that the bottomup process of peace education must be combined with a top-down political process that provides legitimacy and support. Such was the case in Northern Ireland (Racioppi and O'Sullivan 2008) where the movements for integrated schools, "Education for Mutual Understanding," and church-based reconciliatory activities were supported by pressure from the outside-from the United States and the European Union. Neither bottom-up nor top-down strategies, in and of themselves, can suffice for effective peace education.

\section{References}

Abelson, Robert P. 1988. “Conviction.” American Psychologist 43: 267-75.

Arnon, M. 2010. "Reflection on the Contents of a Peace Education Program to Restore the Effects of the Program." Ph.D. diss. University of Haifa (Hebrew).

Bar-On, Dan. 2000. Bridging the Gap. Hamburg: Korber-Stiftung.

Bar-Tal, Daniel. 2000. Shared Beliefs in a Society. Thousand Oaks, CA: Sage.

Bar-Tal, Daniel, and Gavriel Salomon. 2006. "Israeli-Jewish Narratives of the IsraeliPalestinian Conflict: Evolvement, Contents, Functions and Consequences." In Israeli and Palestinian Narratives of Conflict: History's Double Helix, ed. R. I. Rotberg. Bloomington: Indiana University Press, 19-46.

Betancourt, Joseph R., and Andrea E. Reid. 2007. "Black Physicians' Experience with Race: Should We Be Surprised?” Annals of Internal Medicine 146 (1): 68-9. 
Biton, Yifat, and Gavriel Salomon. 2006. "Peace in the Eyes of Israeli and Palestinian Youths as Function of Collective Narratives and Participation in a Peace Education Program." Journal of Peace Research 43 (2): 167-80.

Bowen, Anne M. 2001. "Attitudes toward Lesbian, Gay, and Bisexual College Students: The Contribution of Pluralistic Ignorance, Dynamic Social Impact, and Contact Theories." Journal of American College Health 50 (2): 91-8.

Brown, Kendrick T., Tony N. Brown, James S. Jackson, Robert M. Sellers, and Warde J. Manuel. 2003. "Teammates On and Off the Field? Contact with Black Teammates and the Racial Attitudes of White Student Athletes." Journal of Applied Social Psychology 33 (7): 1379-403.

Coleman, Peter T. 2003. "Characteristics of Protracted, Intractable Conflict: Toward the Development of a Metaframework-I." Peace and Conflict: Journal of Peace Psychology 9 (1): 1-37.

Damon, William, and Erin Phelps. 1989. "Critical Distinctions among Three Approaches to Peer Education." International Journal of Educational Research 13 (1): 9-19.

Desivilya, Helena Syna. 1998. "Jewish-Arab Coexistence in Israel: The Role of Joint Professional Teams." Journal of Peace Research 35 (4): 429-52.

Galtung, Johan. 1996. Peace by Peaceful Means: Peace and Conflict, Development and Civilization. London: Sage.

Gartzke, Erik. 2006. "Identity and Conflict: Ties that Bind and Differences that Divide." European Journal of International Relations 12 (1): 53-87.

Hakvoort, Ilse. 2010. "Peace Education in Regions of Tranquility." In Handbook on Peace Education, eds. Gavriel Salomon and Ed Cairns. New York: Taylor and Francis, 287302.

Halabi, Rabah, and Nava Sonnenshein. 2004. "The Jewish-Palestinian Encounter in a Time of Crisis." Journal of Social Issues 60 (2): 373-87.

Husisi, R. 2007. “The Relationships between Legitimizing the Adversary's Collective Narrative and Adherence to One's Own Narrative as a Function of Participation in a Peace Education Program." Ph.D. diss. University of Haifa (Hebrew).

Jayusi, W. 2009. "Restoring the Attitudes of Peace Education Participate through PeerTutoring." Ph.D. diss. University of Haifa (Hebrew).

Krosnick, Jon A., and Richard E. Petty. 1995. "Attitude Strength: An Overview." In Attitude Strength: Antecedents and Consequences, eds. Richard E. Petty and Jon A. Krosnick. Mahwah, NJ: Erlbaum, 1-24.

Langer, Ellen J. 1997. The Power of Mindful Learning. Cambridge, MA: Perseus Books.

Leippe, Michael R., and Donna Eisenstadt. 1994. "Generalization of Dissonance Reduction: Decreasing Prejudice through Induced Compliance." Journal of Personality and Social Psychology 67: 395-413.

Lentin, Alana. 2004. Racism and Anti-racism in Europe. London: Pluto Press.

Maoz, Ifat. 2004. "Coexistence in the Eyes of the Beholder: Evaluating Intergroup Encounter Interventions between Jews and Arabs in Israel." In Peace Education: The Concept, Principles and Practices around the World, eds. Gavriel Salomon and Baruch Nevo. London: Lawrence Erlbaum Associates, 303-13.

Maoz, Ifat. 2010. "Educating for Peace through Planned Encounters between Jews and Arabs in Israel: A Reappraisal of Effectiveness." In Handbook of Peace Education, eds. Gavriel Salomon and Ed Cairns. New York: Taylor and Francis, 303-14. 
Morris, Mary Lee, and Ian M. Harris. 2003. Peace Education, 2d ed. Jefferson, NC: McFarland and Company.

Peterson, Ruth D., and John Hagan. 1984. "Changing Conceptions of Race: Towards an Account of Anomalous Findings of Sentencing Research.” American Sociological Review 49 (1): 56-70.

Pettigrew, Thomas F., and Linda R. Tropp. 2008. "How Does Intergroup Contact Reduce Prejudice? Meta-analytic Tests of Three Mediators.” European Journal of Social Psychology 38 (6): 922-34.

Polkinghorne, Donald. 1988. Narrative Knowing and the Human Sciences. New York: State University of New York Press.

Racioppi, Linda, and Katherine O’Sullivan. 2008. "Grassroots Peace-building and Thirdparty Intervention: The European Union's Special Support Programme for Peace and Reconciliation in Northern Ireland." Peace and Change 32 (3): 361-90.

Rodgers, Carol. 2002. "Defining Reflection: Another Look at John Dewey and Reflective Thinking." Teacher College Record 104 (4): 842-66.

Roe, Micheál D., and Ed Cairns. 2003. "Memories in Conflict: Review and a Look to the Future." In The Role of Memory in Ethnic Conflict, eds. Ed Cairns and Micheál D. Roe. New York: Palgrave McMillan, 171-80.

Rosen, Yigal, and Gavriel Salomon. 2011. "Durability of Peace Education Effects in the Shadow of Conflict." Social Psychology of Education 14 (1): 135-47.

Ross, M. Horward. 2000. “Good-enough' Isn't So Bad: Thinking about Success and Failure in Ethnic Conflict Management." Peace and Conflict 6 (1): 27-47.

Rouhana, Nadim N., and Daniel Bar-Tal. 1998. "Psychological Dynamics of Intractable Ethnonational Conflicts." American Psychologist 53 (7): 761-70.

Salomon, Gavriel. 2002. "The Nature of Peace Education: Not All Programs Are Created Equal." In Peace Education: The Concept, Principles and Practices around the World, eds. Gavriel Salomon and Baruch Nevo. London: Lawrence Erlbaum Associates, 3-13.

Salomon, Gavriel. 2004. "A Narrative-based View of Coexistence Education." Journal of Social Issues 60 (2): 273-88.

Salomon, Gavriel. 2006. "Does Peace Education Really Make a Difference?" Peace and Conflict: Journal of Peace Psychology 12 (1): 37-48.

Schulze, Kirsten E. 2008. The Arab-Israeli Conflict. 2nd ed. New York: Prentice-Hall.

Shnabel, Nurit, Arie Nadler, Johannes Ullrich, John F. Dovidio, and Dganit Carmi. 2009. "Promoting Reconciliation through the Satisfaction of the Emotional Needs of Victimized and Perpetrating Group Members: The Needs-based Model of Reconciliation." Personality and Social Psychological Bulletin 35: 1021-30.

Siegel, Daniel J. 2007. The Mindful Brain: Reflection and Attunement in the Cultivation of Well-being. New York: Norton.

Smooha, Sammy. 2010. “Index of Arab-Jewish Relations in Israel 2003-2009." http://soc. haifa.ac.il/ s.smooha/uploads/editor_uploads/files/IndexOfArabJewishRelations 2003_2009.pdf (accessed January 12, 2013).

Varshney, Ashutosh. 2002. Ethnic Conflict and Civic Life: Hindus and Muslims in India. New Haven: Yale University Press.

Wu, Shali, and Boaz Keysar. 2007. "The Effect of Culture on Perspective Taking." Psychological Science 18 (7): 600-6.

Zuobi, B. 2007. “The Influence of Participation in Bi-national Soccer Clubs on the 
Perception of 'The Other Side' among Jewish and Arab Youth in Israel.' M.A. thesis. University of Haifa (Hebrew).

Professor Emeritus Gavriel Salomon earned his B.A. and M.A. (Summa cum Laude) at the Hebrew University of Jerusalem in Israel (1966) and Ph.D. in educational psychology and communication at Stanford University (1968). He has taught at various universities around the world, was the dean of the Faculty of Education at the University of Haifa (1993-8), and received a number of international awards, an honorary doctorate and the Israel National Award ("Pras Israel") for life-long achievements in educational research (2001). Salomon has written four books and has published more than 120 empirical, theoretical, and methodological articles in a variety of international professional journals in the fields of technology, learning, cognition, and peace education. Salomon established and directed the Center for Research on Peace Education at the University of Haifa (1999-2012). 
